\title{
The Computer Literacy and Use: The Case of Taiwanese Pre-service Elementary School English Teachers
}

\author{
Li-Tang Yu \\ Department of Curriculum and Instruction \\ The University of Texas at Austin, U. S. A. \\ E-mail: 1tyu@utexas.edu
}

Received: December 20, 2013 Accepted: January 10, 2014 Published: January 10, 2014

doi:10.5296/ijele.v2i1.4897 URL: http://dx.doi.org/10.5296/ijele.v2i1.4897

\begin{abstract}
Language teachers' computer literacy, beliefs, and attitudes toward computer-assisted language learning (CALL) have been widely discussed (e.g. Aydin, 2013; DelliCarpini, 2012; Hong, 2010). However, scant attention has been given to pre-service teachers in Taiwan. This study aims to address this gap in the literature by focusing on the beliefs and attitudes of pre-service elementary school English teachers in Taiwan. The findings report on thirty participants' perceived computer knowledge and skills, the frequency of their technology use, and their attitudes toward the integration of computer use in language learning and teaching. Based on the participants' responses to a survey of computer literacy and use, the results show that the pre-service teachers with different backgrounds and specialties displayed diverse computer literacies. There was an interconnection between the frequency of using a specific computer program and the mastery of the program. A large proportion of the pre-service teachers felt positive about the adoption of technology in their language learning regardless of their various levels of perceived computer literacy. The pedagogical implications, such as the integration of technology use across training sessions and the possibility of using online trainings, are provided. The significance of the study is to offer a picture of Taiwanese pre-service English teachers' computer knowledge and skills. By utilizing this information, the training of computer assisted language learning could be better tailored to fit teachers' needs.
\end{abstract}

Keywords: Computer literacy, Pre-service English teachers, Elementary school, Taiwan 


\section{Introduction}

The Ministry of Education in Taiwan has initiated curricular and instructional reforms since 2000, and added English as a required subject in elementary school (Ministry of Education, n.d.). The curriculum guideline of English explicitly states that students need to develop their competence of information technology so that they can enhance their motivation and broaden their learning experience via the use of computer technology. English teachers could integrate technology into their lessons for students to familiarize with technology use and support students to prepare for the future full of technology.

Educational researchers and teaching practitioners recognize that computer technology can enhance language teaching and learning (e.g. Egbert \& Hanson-Smith, 2007; Warschauer \& Healey, 1998). They also agree that teachers are one of the most important factors influencing the efficacy of computer-assisted language learning (CALL) (Jamieson, Chapelle, \& Preiss, 2005). Thus, researchers and scholars strongly advocate that computer literacy (i.e. the knowledge and ability to use information and communications technology efficiently) is essential for language teachers (DelliCarpini, 2012; Hampel \& Stickler, 2005).

Studies investigating language teachers' computer literacy skills and attitudes toward computer technology for language learning and teaching have been undertaken in several English-as-Second-Language (ESL) and English-as-Foreign-Language (EFL) contexts (e.g. Aydin, 2013; Fuchs \& Akbar, 2013; Yunus, 2007). Research has demonstrated that teachers who used computer technology in their language classrooms were frequently those who already had prior experience with CALL (Egbert, Paulus, \& Nakamichi, 2002). If there were greater understanding about pre-service language teachers' computer literacies and use, the design of CALL training could better fit the teachers' professional development. Unfortunately, few studies have addressed this issue in the Taiwanese context (cf. Yu \& Sardegna, 2012). As a replication of Yu and Sardegna's (2012) study, this research aims to address the gap by exploring Taiwanese pre-service elementary school English teachers' computer literacy skills and experiences with technology. In the next sections, relevant literature on language teachers' computer literacy skills and use is described.

\section{Literature Review}

Previous research exploring language teachers' computer literacy skills has been conducted in Asia (Albilirini, 2006; Aydin, 2013; Chen, 2012; Li \& Walsh, 2011; Park \& Son, 2009; Shin \& Son, 2007; Son, Robb, \& Charismiadji, 2011; Sumi, 2010; Yunus, 2007), Europe (Dooly, 2009; Fuchs, 2006), North America (Fuchs \& Akbar, 2013; Kessler \& Plakans, 2008; Lam, 2000; Meskill, Anthony, Hilliker-Vanstrander, \& You, 2006; Wiebe \& Kabata, 2010), and South America (Barsotti \& Martins, 2010). It has been demonstrated that increased access to technology facilities does not guarantee that language teachers would always integrate CALL into their instruction. Teachers' computer literacy and perceptions about CALL have also been considered, as shall be reviewed in the following section.

\subsection{Language Teachers ' Computer Literacy}

A survey approach is one of the most popular methodologies employed to investigate 
language teachers' use of computer technology. Language teachers have demonstrated diverse computer literacies and held different attitudes regarding specific software applications. For example, Son et al. (2011) surveyed 73 Indonesian EFL in-service teachers, and found that although the teachers perceived themselves as having high technical skills, their application of computer technology was limited to only few programs, such as Word Processing. The application of concordancers and computer-mediated communication (CMC) seemed foreign to the teachers.

Aydin (2013) examined 157 Turkish EFL teachers' perceptions of computer use for instruction. The results showed that the teachers' computer literacies were restricted to the use of Internet, email, word processing, and presentation software. Yunus (2007) noted that 444 Malaysian ESL teachers in technical schools minimally used information and communications technology (ICT) in class. Reporting results from surveys and interviews, Park and Son (2009) investigated how 12 EFL secondary-school teachers in South Korea used computers in class. Internet and CD-ROMs were the tools most frequently utilized by these teachers due to their ease of application.

Barsotti and Martins (2010) demonstrated that the levels of computer literacy exhibited by 63 Brazilian foreign language teachers varied greatly. Some of the teachers were not even familiar with basic software applications. Their computer knowledge was not sufficient to implement ICT into their teaching practices. The researchers asserted that the phenomenon of heterogeneity in language teachers' computer literacy is expected in light of the teachers' various academic and professional backgrounds. They suggested that teachers' CALL training focus more on practical (i.e. hands-on activities) than theoretical aspects. Moreover, the authors suggested that training needs to be evaluated and adjusted to keep up with global trends and the evolution of technology, and to meet students' specific learning needs.

\subsection{Language Teachers'Attitudes and Beliefs about CALL Use}

Teachers' attitudes toward and beliefs about computer technology have been considered a critical factor for the success of technology implementation in education (Fuchs, 2006; Woodrow, 1992). Despite the diverse picture of language teachers' computer literacies, most research illustrates that a large proportion of language teachers consider CALL implementation beneficial for their instruction (Albilirini, 2006; Aydin, 2013; Bordbar, 2010; Li \& Walsh, 2011; Park \& Son, 2009; Yunus, 2007).

Drawing upon generalized responses to open-ended items in technology use surveys from 39 teachers in an intensive English program in the U. S., Fuchs and Akbar (2013) suggested that teachers' attitudes would affect their willingness to adopt technology. In these surveys, the teachers maintained that technology could not replace face-to-face communication, even though they recognized the strength of using technology in class, such as incorporating authentic materials and engaging students.

Furthermore, researchers have compared the views of different groups of language teachers about CALL use. For example, Wiebe and Kabata (2010) found that there was a gap between language teachers' and learners' perceptions regarding computer use and the types of 
technology tools beneficial to learning achievement. The teachers did not always accurately judge their students' use of CALL applications. Meskill, Mossop, DiAngelo, and Pasquale (2002) found differences between expert and novice language teachers' use of computer technology in classroom management and instruction. The expert teachers skillfully viewed technology as teaching and learning tools and paid more attention to supporting students' learning motivation and process via technology utilization. On the other hand, the novice teachers considered technology as tools for controlling learners and focused more on how to use technology and on the outcome of using technology.

\section{This Project}

Based on the previous literature review of teachers' computer literacies, a number of factors influencing language teachers' CALL use have been identified. Several aspects are associated with language teachers themselves. For example, language teachers' affect (Shin \& Son 2007), prior experiences of using technology (Egbert, Paulus, \& Nakamichi, 2002), attitudes toward CALL adoption (Chen, 2012; Kessler \& Plakans 2008; Lam, 2000), and their capabilities in using technology in instruction (Lam, 2000; Park \& Son 2009; Shin \& Son 2007) influence their willingness to integrate ICT into their teaching. Moreover, influential factors connected with teaching contexts have been identified in other studies. Among them, the administrators' support (Aydin, 2012; Lam, 2000; Yunus, 2007) and curriculum design (Park \& Son, 2009; Sumi, 2010) appear to play an important role in the practices of language teachers' technology use for instruction.

There are many issues worthy of consideration when it comes to language teachers' implementation of CALL. In the context of elementary schools in Taiwan, educational authorities have provided technology facilities to schools in recent years due to the increasing focus on computer-assisted instruction (Wen \& Shih, 2008). However, making these facilities accessible is but one aspect influencing CALL implementation. In light of the research findings presented thus far, it is important to shed light on how prospective language teachers perceive their computer competence and what training they require in order to enhance their development of computer literacy. These issues serve as the impetus for the current study. The following sections report on a study investigating Taiwanese pre-service language teachers' computer knowledge and skills, and attitudes toward CALL. Three research questions guide the study:

1. How do pre-service language teachers in Taiwan evaluate their computer literacy and skills, and their frequency of technology use?

2. What are the pre-service teachers' attitudes toward using computers for language teaching and learning?

3. Is there a relationship between the teachers' levels of computer literacy and their attitudes toward computer use?

\section{Method}

\subsection{Setting and Participants}

The study was conducted in a university-level course about designing English learning 
activities for elementary school students in Taiwan. The course was required for students who seek certification to teach English in elementary schools. The course instructor and the students met weekly two hours over 18 weeks. The instructional mode was discussion-based.

Thirty Taiwanese pre-service teachers in the course ( 9 males and 21 females) volunteered to participate in this study. They were all enrolled in the training program of pre-service elementary school English teachers. The participants' specialties are shown in Table 1.

Table 1 . The specialty of the pre-service teachers

\begin{tabular}{ll}
\hline Specialty & Number \\
\hline Art Education & $1(3.33 \%)$ \\
Childhood Education & $1(3.33 \%)$ \\
Educational Psychology & $2(6.67 \%)$ \\
English Instruction & $5(16.67 \%)$ \\
Mandarin Instruction & $9(30 \%)$ \\
Math Education & $2(6.67 \%)$ \\
Music Education & $5(16.67 \%)$ \\
Science Education & $1(3.33 \%)$ \\
Social Studies & $2(6.67 \%)$ \\
Special Education & $2(6.67 \%)$ \\
\hline
\end{tabular}

Note. $\mathrm{N}=30$

Fifty-seven percent of the pre-service teachers were in the third year of the professional development program $(n=17), 30 \%$ were in the second year, and $13 \%$ were in the fourth year. The average age of study participants was approximately 22 years (ranging from 20 to 42 years of age), and their average years of computer use was 9.3 (ranging from three to 15 years). All but two pre-service teachers had regular access to computer facilities with Internet connection. Forty percent of the participants $(n=12)$ stated that they had learned computer technology from other teachers at school; 37\% $(n=11)$ reported that they had acquired this learning from family members; $20 \%(\mathrm{n}=6)$ were self-trained, and $3 \%(\mathrm{n}=1)$ learned from classmates.

\subsection{Instrument}

The data were gathered through a questionnaire modified from Son et al. (2011). The survey consisted of three sections: (a) background information, (b) computer literacy and skills, and (c) attitudes toward using computers for language learning and teaching. The items in section (b) and (c) were all closed-ended. All survey items were translated into Mandarin, making them accessible to the participants in both English and Mandarin. 


\subsection{Data Collection and Analysis}

The researcher explicated the purpose of the study, procedure, instructions for the questionnaire, and benefits and potential risks of the study at the last class of the course. The participants were assured that their course grade would not be affected by whether or not they decided to answer the questionnaire. The pre-service teachers who participated in this survey completed the survey away from class and retuned completed surveys to the researcher. Thirty-five surveys were returned; however, five were eliminated from consideration because they were returned incomplete.

Due to the exploratory nature of the study and limited sample size, descriptive statistics were used to analyze the participants' responses to the survey. Inferential statistics were used to examine the relationship between the participants' perceived computer literacies and their attitudes toward computer use.

\section{Results and Discussion}

\subsection{Taiwanese Pre-service Teachers'Self-reported Computer Literacy and Skills}

At the start of the survey, the participants were asked to evaluate their computer literacies. Only one participant (3.3\%) answered "excellent," six (20\%) expressed "good," 70\% (n=21) reported "adequate," and two (6.7\%) reported having "poor" computer literacy knowledge. These findings corroborate those of Barsotti and Martin's (2010) study: both pre-service and in-service teachers demonstrated heterogeneous knowledge about computer technology because of different backgrounds. Although the majority of the participants could be labeled as "digital natives" (Thompson, 2013) who were in their early 20s and surrounded with digital media all day long, in actuality most of them only considered themselves to have adequate computer knowledge and skills with technology. Thus, the participants were aware that they were not well-equipped with knowledge and skills of computer use.

Next, the participants were asked about their specific computer skills, knowledge of general program applications, and the use of computer programs. The results are shown in Tables 2-4. In Table 2, there are 28 yes/no questions exploring specific computer skills. The participants expressed that they were capable of using most of the basic computer skills in the survey, such as turning the computer on and off, managing files in the computer and in e-mail programs, using CD-ROMs, starting and exiting programs, using a USB drive, printing documents, and processing texts in a word document. However, a third of the participants noted their inability to understand the computer hardware functions and to process sounds. Furthermore, over $50 \%$ of the participants reported not being able to create a web page and use a database program. These results suggest that the participants had acquired fundamental skills for computer use but still felt incompetent in certain computer applications that were more complex. The results of this survey indicate that there is a need for pre-service teachers to undertake training for acquiring more advanced computer skills. 
Table 2. Self-evaluation of specific computer skills

\begin{tabular}{l} 
Questions \\
\hline 1. Do you have an e-mail account? \\
2. Can you use CD-ROMs? \\
3. Can you properly turn on and shut down a computer? \\
4. Can you start and exit a computer program? \\
5.Can you perform file management including deleting and \\
renaming files, etc.?
\end{tabular}

6. Can you move a file from a hard drive to a USB drive?

7. Can you print a document using a printer?

$\begin{array}{ll}30(100 \%) & 0(0 \%) \\ 30(100 \%) & 0(0 \%) \\ 30(100 \%) & 0(0 \%) \\ 30(100 \%) & 0(0 \%)\end{array}$

9. Can you copy, cut and paste text in a document?

$30(100 \%) \quad 0(0 \%)$

11. Can you send and receive attachments through e-mail $30(100 \%) \quad 0(0 \%)$ messages?

12. Do you use keyboard shortcuts?

$29(96.7 \%) \quad 1(3.3 \%)$

13. Can you use a 'search' command to locate a file?

$29(96.7 \%)$

$1(3.3 \%)$

14. Can you create a simple presentation using PowerPoint?

$29(96.7 \%)$

$1(3.3 \%)$

15.Can you search for information online using a Web

$29(96.7 \%)$

$1(3.3 \%)$ search engine?

16.Can you download and save files from the Web (e.g., text, graphic, PDF files)?

17. Can you change monitor brightness and contrast?

$29(96.7 \%)$

$1(3.3 \%)$

18.Can you minimize, maximize and move windows on the

$28(93.3 \%)$

$2(6.7 \%)$ desktop?

$28(93.3 \%)$

$2(6.7 \%)$

19. Can you resize a photograph?

$28(93.3 \%) \quad 2(6.7 \%)$

20. Can you install a software program?

$27(90 \%)$

$3(10 \%)$

21. Can you scan disks for viruses?

$27(90 \%)$

$3(10 \%)$

22. Can you use a video conferencing tool on the Web?

$26(86.7 \%)$

$4(13.3 \%)$

23. Can you create a basic Excel spreadsheet?

$25(83.3 \%)$

$5(16.7 \%)$

24. Can you write files onto a CD?

$22(73.3 \%)$

$8(26.7 \%)$

25.Do you understand the basic functions of computer

$20(66.7 \%)$

$10(33.3 \%)$ hardware components?

26. Can you record and edit sounds?

$20(66.7 \%) \quad 10(33.3 \%)$

27. Can you create a simple Web page?

$14(46.7 \%)$

$16(53.3 \%)$

28. Can you create a simple database using Access?

$9(30 \%)$

$21(70 \%)$

Note. $\mathrm{N}=30$ 
Table 3 shows the results of the participants' evaluations of their level of knowledge (ranging on a scale of 1 to 4, from none (1), to basic (2), to intermediate (3), and to advanced (4)) regarding word processing, spreadsheet, databases, presentation, multimedia, web design, web search, and communication. Their responses display that over $60 \%$ of the participants considered themselves as possessing at least an intermediate level understanding of communication $(M=2.83)$ and word processing $(M=2.7)$. Half of the participants reported intermediate or advanced control over web search engines $(M=2.57)$. However, $60 \%$ of respondents reported basic skills or no skills at all for utilizing multimedia $(M=2.40)$ and presentation $(M=2.17)$. The majority of participants (over $75 \%)$ had basic or less than basic abilities in using databases $(M=2.00)$ and spreadsheets $(M=1.97)$.

Table 3. Self-evaluation of general program applications

\begin{tabular}{lllllll}
\hline Applications & Advanced & Intermediate & Basic & None & $M$ & $S D$ \\
\hline 1. Communication & $8(26.7 \%)$ & $11(36.7 \%)$ & $9(30 \%)$ & $2(6.7 \%)$ & 2.83 & 0.91 \\
2. Word processing & $3(10 \%)$ & $16(53.3 \%)$ & $11(36.7 \%)$ & $0(0 \%)$ & 2.70 & 0.70 \\
$\begin{array}{l}\text { 3. Web search } \\
\text { engines }\end{array}$ & $4(13.3 \%)$ & $11(36.7 \%)$ & $13(43.3 \%)$ & $2(6.7 \%)$ & 2.57 & 0.82 \\
4. Multimedia & $1(3.3 \%)$ & $11(36.7 \%)$ & $17(56.7 \%)$ & $1(3.3 \%)$ & 2.40 & 0.62 \\
5. Presentation & $2(6.7 \%)$ & $10(33.3 \%)$ & $9(30 \%)$ & $9(30 \%)$ & 2.17 & 0.95 \\
6. Database & $1(3.3 \%)$ & $6(20 \%)$ & $15(50 \%)$ & $8(26.7 \%)$ & 2.00 & 0.79 \\
7. Spreadsheet & $0(0 \%)$ & $5(16.7 \%)$ & $19(63.3 \%)$ & $6(20 \%)$ & 1.97 & 0.61 \\
8. Web design & $1(3.3 \%)$ & $3(10 \%)$ & $10(33.3 \%)$ & $16(53.3 \%)$ & 1.63 & 0.81 \\
\hline
\end{tabular}

Note. $\mathrm{N}=30$

Table 4 shows how frequently the participants used 16 general application software programs. Respondents reported that all of them used Word Processing, checked their e-mail, and browsed web pages at least 3-4 times per week. Over $70 \%$ of the participants infrequently used or never used spreadsheet, graphics, voice chatting, video conferencing, and computer games. Twelve (40\%) participants reported that they did not use online discussion groups at all. Regarding databases, multimedia, language software (CD-ROM), concordancer, blogging, and wiki, the participants indicated that they used them at least once or twice a month. 
Table 4. Frequency of using computer programs

\begin{tabular}{|c|c|c|c|c|c|}
\hline Programs & $\begin{array}{l}\text { Almost } \\
\text { everyday }\end{array}$ & $\begin{array}{l}\text { 3-4 times per } \\
\text { week }\end{array}$ & $\begin{array}{l}\text { 1-2 times per } \\
\text { week }\end{array}$ & $\begin{array}{l}1-2 \text { times per } \\
\text { month }\end{array}$ & $\begin{array}{l}\text { Never used/ } \\
\text { do not know }\end{array}$ \\
\hline $\begin{array}{l}\text { 1. Word } \\
\text { processing }\end{array}$ & $17(56.7 \%)$ & $12(40 \%)$ & $1(3.3 \%)$ & $0(0 \%)$ & $0(0 \%)$ \\
\hline 2. E-mail & $19(63.3 \%)$ & $9(30 \%)$ & $1(3.3 \%)$ & $1(3.3 \%)$ & $0(0 \%)$ \\
\hline 3. WWW & $28(93.3 \%)$ & $2(6.7 \%)$ & $0(0 \%)$ & $0(0 \%)$ & $0(0 \%)$ \\
\hline 4. Database & $5(16.7 \%)$ & $7(23.3 \%)$ & $9(30 \%)$ & $3(10 \%)$ & $6(20 \%)$ \\
\hline 5. Spreadsheet & $1(3.3 \%)$ & $1(3.3 \%)$ & $4(13.3 \%)$ & $18(60 \%)$ & $6(20 \%)$ \\
\hline 6. Graphics & $2(6.7 \%)$ & $3(10 \%)$ & $4(13.3 \%)$ & $8(26.7 \%)$ & $13(43.3 \%)$ \\
\hline 7. Multimedia & $10(33.3 \%)$ & $7(23.3 \%)$ & $6(20 \%)$ & $6(20 \%)$ & $1(3.3 \%)$ \\
\hline $\begin{array}{l}\text { 8.Language } \\
\text { software } \\
\text { (CD-ROM) }\end{array}$ & $1(3.3 \%)$ & $1(3.3 \%)$ & $10(33.3 \%)$ & $10(33.3 \%)$ & $8(26.7 \%)$ \\
\hline 9. Concordancer & $3(10 \%)$ & $5(16.7 \%)$ & $11(36.7 \%)$ & $7(23.3 \%)$ & $4(13.3 \%)$ \\
\hline 10. Blogging & $2(6.7 \%)$ & $6(20 \%)$ & $8(26.7 \%)$ & $10(33.3 \%)$ & $4(13.3 \%)$ \\
\hline 11. Wiki & $0(0 \%)$ & $6(20 \%)$ & $13(43.3 \%)$ & $9(30 \%)$ & $2(6.7 \%)$ \\
\hline $\begin{array}{l}\text { 12.Online } \\
\text { discussion groups }\end{array}$ & $7(23.3 \%)$ & $2(6.7 \%)$ & $6(20 \%)$ & $3(10 \%)$ & $12(40 \%)$ \\
\hline 13.Text chatting & $14(46.6 \%)$ & $7(23.3 \%)$ & $6(20 \%)$ & $3(10 \%)$ & $0(0 \%)$ \\
\hline 14. Voice chatting & $3(10 \%)$ & $2(6.7 \%)$ & $2(6.7 \%)$ & $13(43.3 \%)$ & $10(33.3 \%)$ \\
\hline $\begin{array}{l}\text { 15.Video } \\
\text { conferencing }\end{array}$ & $0(0 \%)$ & $0(0 \%)$ & $4(13.4 \%)$ & $7(23.3 \%)$ & $19(63.3 \%)$ \\
\hline $\begin{array}{l}\text { 16.Computer } \\
\text { games }\end{array}$ & $5(16.7 \%)$ & $3(10 \%)$ & $6(20 \%)$ & $10(33.3 \%)$ & $6(20 \%)$ \\
\hline
\end{tabular}

Note. $\mathrm{N}=30$

\subsection{Taiwanese Teachers' Attitudes toward Using Computers for Language Learning and Teaching}

The next part of the survey included eight items with a 5-point Likert scale ( $5=$ strongly agree, $1=$ strongly disagree) to investigate the participants' attitudes toward using ICT for language learning and teaching. Table 5 shows that the mean scores for all surveyed items were above 
four, indicating that the participants agreed with the item statements and showed positive sentiments about using ICT. In general, participants expressed comfort in and enjoyment with using ICT, and were willing to adopt it in their future teaching.

Table 5. Pre-service teachers' attitudes toward using computers

\begin{tabular}{|c|c|c|}
\hline Questions & Mean & $S D$ \\
\hline 1. I enjoy using computers for language learning. & 4.40 & 0.67 \\
\hline 2. I feel comfortable using computers for language learning. & 4.19 & 0.74 \\
\hline $\begin{array}{l}\text { 3. I am willing to learn more about how to use computers for } \\
\text { language learning. }\end{array}$ & 4.38 & 0.71 \\
\hline $\begin{array}{l}\text { 4. I believe that it is important for me to learn how to use } \\
\text { computers for language teaching. }\end{array}$ & 4.44 & 0.91 \\
\hline 5. I would like to use computers in my future teaching. & 4.31 & 0.69 \\
\hline $\begin{array}{l}\text { 6. I think that my language teaching and learning can be } \\
\text { improved by using computers. }\end{array}$ & 4.30 & 0.54 \\
\hline $\begin{array}{l}\text { 7. I think that computers can make second/foreign language } \\
\text { teaching and learning interesting. }\end{array}$ & 4.17 & 0.70 \\
\hline $\begin{array}{l}\text { 8. I believe that training in computer-assisted language learning } \\
\text { should be included in language teacher education programs. }\end{array}$ & 4.23 & 0.63 \\
\hline
\end{tabular}

Note. 5 Strongly agree; 4 Agree; 3 Uncertain; 2 Disagree; 1 Strongly disagree.

To further investigate if the participants' perceived computer literacies would relate to their attitudes toward the use of computers in their teaching, a correlation analysis was conducted. The results revealed no significant findings. The participants recognized the application of computer technology for language learning and teaching regardless of their levels of computer literacy.

\section{Discussion}

The survey responses indicate that the participants had various profiles of computer literacy and use. Their diverse levels of computer proficiency correspond to those of teachers in other EFL contexts, such as in Brazil (Barsotti \& Martins, 2010), in Indonesia (Son et al., 2011), in Korea (Park \& Son, 2009), and in Turkey (Aydin, 2012), who displayed similar profiles of being adept at specific computer applications. This study's results suggest that language teachers with certain computer skills are universal.

The findings of the current study are in line with previous studies conducted in other 
EFL/ESL contexts (Aydin, 2013; Barsotti \& Martins, 2010; Meskill et al., 2006), demonstrating that pre-service teachers were proficient with using specific computer applications, such as word processing, web search engines, and communication tools. Further, the results echo Yu and Sardegna's (2012) study, suggesting that elementary school teachers in Taiwan had limited knowledge of and skills in web design and databases. However, it is surprising to find that $60 \%$ of the pre-service teachers in the training program possessed at most only basic competency when using presentation applications. They were always required to make presentations in other courses and had many opportunities to use presentation applications. Given these results, it appears that pre-service and in-service elementary school teachers in Taiwan do not have adequate training in terms of web design and databases use, and thus need more training to broaden participants' repertoires of computer use. Furthermore, trainings in the use of applications need to be carefully tailored so as to better meet specific needs of various teacher populations.

Another finding indicates that the more frequently pre-service teachers used these programs, the more proficient they rated themselves concerning the use of these programs, such as the application of word processing and Internet. Plus, they were less proficient at programs (e.g. spreadsheet) that they infrequently used. As Kessler and Plakans (2008) observed, teachers' willingness to use technology applications is contingent on their computer literacy. However, one computer application contradicted this claim. Regardless of their low competence of databases, nearly $70 \%$ of the participants still used databases at least once or twice per week. This curious finding might be explained by the assumption that participants' basic knowledge of using databases was sufficient to cope with their current needs and that participants were satisfied with using simple functions of databases. Further exploration about this phenomenon is needed.

In concert with the results of the previous literature (e.g., Adyin, 2012; Park \& Song, 2009; Son et al., 2011; Yunus, 2007), the pre-service teachers included in this study recognized the importance of computers for language instruction and learning, appreciated the use of ICT, and were motivated to learn more about technology-enhanced language teaching and learning. According to Egbert et al. (2002), teachers with previous experience using computer technology are mostly likely to use it in their teaching practices. As such, CALL training would not only help pre-service teachers acquire the knowledge of computer literacy, but also provide them with opportunities to actually utilize computer applications in their own teaching and learning. The pre-service teachers in the current study considered CALL training essential in their professional development, corroborating results from Dellicarpini (2012). Furthermore, no relationship between the teachers' fondness with CALL and their levels of computer literacy suggests that the pre-service teachers with different levels of computer literacy considered technology an essential role in their current language learning and future instruction.

\subsection{Limitations of the Study}

Although this study yields several compelling findings that merit serious consideration, certain study limitations need to be addressed. The small sample size limits the 
generalizability of the study results. Moreover, the survey results might not necessarily reflect participants' actual technology application. The participants' self-evaluation of computer literacy cannot be directly translated into their actual competence (Son et al., 2011). To triangulate the study results, data collected from various methods (e.g. interviews, observations, and computer use diary) might provide a more robust understanding of this relationship. Future studies that investigate the development of pre-service language teachers' computer literacies might do well to examine their training processes and outcomes, and to seek to explore links between the two.

\section{Conclusion}

The participants involved in this study reported diverse, self-evaluated computer literacies and provided distinctive viewpoints on using computer technology for language teaching as well as learning. Instructors can better develop CALL training for pre-service language teachers by taking advantage of this information. Due to pre-service teachers' heterogeneous backgrounds and specialties, their different perspectives are worth considering when it comes to the design of training programs. According to their responses to this study's survey, the majority of the participants perceived that they acquired "adequate" computer knowledge and understood fundamental computer skills. Their levels of computer literacy influenced the frequency of using specific program applications in most cases. However, despite the fact that their perceived computer literacies varied, respondents indicated that they still felt positive about the adoption of technology in their English learning and teaching.

This study has three implications for enhancing pre-service language teachers' computer literacies. First, pre-service teachers' repertoires of computer application must be broadened in order to cope with their learning and teaching needs. As previous literature suggests, technology training can help teachers improve their computer competence (Aydin, 2013). In particular, online training sessions may be a possible venue for pre-service teachers. With online training, teachers can freely choose which computer programs they need to learn, and flexibly manage their time to attend the online training without the conventional time and location constraints of in-person training sessions. Moreover, in this venue pre-service teachers can benefit from the hands-on experience of using computer technology to learn about this technology.

Secondly, it is important for pre-service teachers to increase their exposure to a variety of program applications. To achieve this end, instructors in training programs might demonstrate how to integrate technology into class by regularly utilizing various computer applications across the curriculum, and by encouraging pre-service teachers to become proficient in using technology. In this way, pre-service teachers might gain more understanding of using a range of technology applications for prospective language teaching. With increased experiences and boosted confidence, pre-service teachers might become more willing and motivated to implement CALL activities for instruction (Egbert et al., 2002; Kessler \& Plakans, 2008).

Finally, it is essential to encourage pre-service teachers to become autonomous ICT learners so as to cope with the fast advancement of computer technology. One strategy to accomplish this goal might be to encourage pre-service teachers to form learning groups to tackle 
technology issues together. By doing so, they might draw upon their diverse computer competencies and skills to provide and receive support from one other. Through enhanced support, pre-service teachers may increase their capabilities using technology and be willing to try different technology applications for their language learning and teaching.

\section{References}

Albilirini, A. (2006). Teachers' attitudes towards information and communication technologies: the case of Syrian EFL Teachers. Computers \& Education, 47(4), 373-398. http://dx.doi.org/10.1016/j.compedu.2004.10.013

Aydin, S. (2013). Teachers' perceptions about the use of computers in EFL teaching and learning: the case of Turkey. Computer Assisted Language Learning, 26(3), 1-20. http://dx.doi.org/10.1080/09588221.2012.654495

Barsotti, C., \& Martins, C. (2010). The use of ICTs in foreign language teaching. In M. Levy, F. Blin, C. B. Siskin, \& O. Takeuchi (Eds.), WorldCALL: International perspectives on computer-assisted language learning (pp. 241-256). Hoboken: Taylor \& Francis.

Bordbar, F. (2010). English teachers' attitudes towards computer-assisted language learning. International Journal of Language Studies, 4(3), 27-54. Retrieved from http://www.bcl.edu.ar/spip/IMG/pdf/bordbar2.pdf

Chen, K. T. (2012). Elementary EFL teachers computer phobia and computer self-efficacy in Taiwan. The Turkish Online Journal of Educational Technology, 11(2), 100-107. Retrieved from http://www.tojet.net/articles/v11i2/11210.pdf

DelliCarpini, M. (2012). Building computer technology skills in TESOL teacher education. Language Learning \& Technology, 16(2), 14-23. Retrieved from http://1lt.msu.edu/issues/june2012/action.pdf

Dooly, M. (2009). New competencies in a new era? Examining the impact of a teacher training project. ReCALL, 21(3), 352-369. http://dx.doi.org/10.1017/S0958344009990085

Egbert, J., \& Hanson-Smith, E. (Ed.) (2007). CALL environments: Research, practice, and critical issues. Alexandria, VA: TESOL.

Egbert, J., Paulus, T.M., \& Nakamichi, Y. (2002). The impact of CALL instruction on classroom computer use: A foundation for rethinking technology in teacher education. Language Learning \& Technology, 6(3), 108-126. Retrieved from http://lt.msu.edu/vol6num3/egbert/default.html

Fuchs, C. (2006). Exploring German preservice teachers' electronic and professional literacy skills. ReCALL, 18(2), 174-192. http://dx.doi.org/10.1017/S0958344006000322

Fuchs, C., \& Akbar, F. S. (2013). Use of Technology in an Adult Intensive English Program: Benefits and Challenges. TESOL Quarterly, 47(1), 156-167. http://dx.doi.org/10.1002/tesq.80

Guichon, N., \& Hauck, M. (2011). Teacher education research in CALL and CMC: More in demand than ever. ReCALL, 23(3), 187-199. http://dx.doi.org/10.1017/S0958344011000139

Hampel, R., \& Stickler, U. (2005). New skills for new classrooms: Training tutors to teach 
languages online. Computer Assisted Language Learning, 18(4), 311-326. http://dx.doi.org/10.1080/09588220500335455

Hong, H. K. (2010). CALL teacher education as an impetus for L2 teachers in integrating technology. ReCALL, 22(1), 53-69. http://dx.doi.org/10.1017/S095834400999019X

Hubbard, P. (2008). CALL and the future of language teacher education. CALICO Journal, 25(2), 175-188. http://dx.doi.org/10.11139/cj.25.2.175-188

Jamieson, J., Chapelle, C., \& Preiss, S. (2005). CALL evaluation by developers, a teacher, and students. CALICO Journal, 23(1), 93-138. http://dx.doi.org/10.11139/cj.23.1.93-138

Kessler, G., \& Plakans, L. (2008). Does teachers' confidence with CALL equal innovative and integrated use? Computer Assisted Language Learning, 21(2), 169-282. http://dx.doi.org/10.1080/09588220802090303

Lafford, B. A. (2009). Towards an ecological CALL: Update to Garret (1991). The Modern Language Journal, 93(Focus 673-696. http://dx.doi.org/10.1111/j.1540-4781.2009.00966.x

Lam, Y. (2000). Technophilia vs. technophobia: A preliminary look at why second-language teachers do or do not use technology in their classrooms. The Canadian Modern Language Review, 56(3), 389-420. http://dx.doi.org/10.3138/cmlr.56.3.389

Li, L., \& Walsh, S. (2011). Technology uptake in Chinese EFL classes. Language Teaching Research, 15(1), 99-125. http://dx.doi.org/10.1177/1362168810383347

Meskill, C., Anthony, N., Hilliker-Vanstrander, S., Tseng, C.-H., \& You, J. (2006). CALL: A survey of K-12 ESOL teacher uses and preferences. TESOL Quarterly, 40(2), 439-451. http://dx.doi.org/10.2307/40264532

Meskill, C., Mossop, J., DiAngelo, S., \& Pasquale, R. K. (2002). Expert and novice teachers talking technology: Precepts, concepts, and misconcepts. Language Learning \& Technology, 6(3), 46-57. Retrieved from http://1t.msu.edu/vol6num3/meskill/default.html

Ministry of Education. (n.d.). General guidelines of grades 1-9 curriculum for elementary and junior high school education. Retrieved from http://teach.eje.edu.tw/9CC2/9cc_97.php

Park, C.-N., \& Son, J.-B. (2009). Implementing computer-assisted language learning in the EFL classroom: Teachers' perceptions and perspectives. International Journal of Pedagogies and Learning, 5(2), 80-101. http://dx.doi.org/10.5172/ijpl.5.2.80

Shin, H.-J., \& Son, J.-B. (2007). EFL teachers' perceptions and perspectives on Internet-assisted language teaching. CALL-EJ, 8(2). Retrieved from http://callej.org/journal/8-2/h-js_j-bs.html

Son, J.-B., Robb, T., \& Charismiadji, I. (2011). Computer Literacy and Competency: A survey of Indonesian teachers of English as a foreign language. CALL-EJ, 12(1), 26-42. Retrieved from http://callej.org/journal/12-1/Son_2011.pdf

Stepp-Greany, J. (2002). Student perceptions on language learning in a technological environment: Implications for the new millennium. Language Learning \& Technology, 6(1), 
165-180. Retrieved from http://www.llt.msu.edu/vol6num1/steppgreany/default.html

Stockwell, G. (2009). Teacher education in CALL: Teaching teachers to educate themselves. Innovation in Language Learning and Teaching, 3(1), 99-112. http://dx.doi.org/10.1080/17501220802655524

Sumi, S. (2010). Voices from EFL teachers: A qualitative investigation of teachers' use of CALL. In M. Levy, F. Blin, C. B. Siskin, \& O. Takeuchi (Eds.), WorldCALL: International perspectives on computer-assisted language learning (pp. 293-312). Hoboken: Taylor \& Francis.

Thompson, P. (2013). The digital natives as learners: Technology use patterns and approaches $\begin{array}{lllll}\text { to learning. Computers } \& \text { Education, } & 65, & 12-23 .\end{array}$ http://dx.doi.org/10.1016/j.compedu.2012.12.022

Warschauer, M., \& Healey, D. (1998). Computers and language learning: An overview. Language teaching, 31(2), 57-71. http://dx.doi.org/10.1017/S0261444800012970

Wen, J. R., \& Shih, W. L. (2008). Exploring the information literacy competence standards for elementary and high school teachers. Computers \& Education, 50(3), 787-806. http://dx.doi.org/10.1016/j.compedu.2006.08.011

Wiebe, G., \& Kabata, K. (2010). Students' and instructors' attitudes towards the use of CALL in foreign language teaching and learning. Computer Assisted Language Learning, 23(3), 221-234. http://dx.doi.org/10.1080/09588221.2010.486577

Winke, P., \& Goertler, S. (2008). Did we forget someone? Students' computer access and

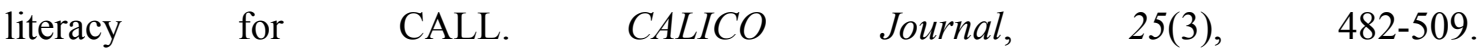
http://dx.doi.org/10.11139/cj.25.3.482-509

Woodrow, J. E. (1992). The influence of programming training on the computer literacy and attitudes of preservice teachers. Journal of research on Computing in Education, 25(2), 200-19.

Yu, L. T., \& Sardegna, V. (2012). Experienced teachers' computer literacy and use: Implications for language teaching. Paper presented at the 2012 TexTESOL Region III Fall Conference, Oct 13. Austin, Texas.

Yunus, M. M. (2007). Malaysian ESL teachers' use of ICT in their classrooms: expectations and realities. ReCALL, 19(1), 79-95. http://dx.doi.org/10.1017/S0958344007000614

\section{Copyright Disclaimer}

Copyright reserved by the author(s).

This article is an open-access article distributed under the terms and conditions of the Creative Commons Attribution license (http://creativecommons.org/licenses/by/3.0/). 